\title{
OS ÍNDIOS VEREADORES, A CÂMARA DE MESSEJANA E A FORMAC̣ÃO DO ESTADO NACIONAL BRASILEIRO NO CEARÁ
}

The indigenous councilors, the council of Messejana and the formation of the Brazilian national state

\section{RESUMO}

Este artigo analisa a cultura política dos vereadores indígenas da vila de índios de Messejana e sua relação com a câmara municipal durante a formação do Estado brasileiro no Ceará. Essas lideranças atuaram no senado da vila desde a promulgação do Diretório dos Índios no século XVIII, mas suas prerrogativas foram usurpadas em nome da cidadania prevista na Constituição de 1824. Priorizando a produção documental da câmara municipal de Messejana, o artigo analisa os posicionamentos indígenas durante a voga liberal e como se processou a degradação de seus direitos com a formação do Estado nacional brasileiro.

Palavras-chave: índios, câmaras municipais, cultura política, independência do Brasil, cidadania.

\begin{abstract}
This article analyzes the political culture of the indigenous councilors of the Messejana Indian village and their relationship with the city council during the formation of the Brazilian state in Ceará. These leaders have worked in the village senate since the promulgation of the Directorate of Indians in the 18th century, but their prerogatives were usurped in the name of the citizenship provided for in the 1824 Constitution. Prioritizing the documentary production of the Messejana city council, this article analyzes the indigenous positions during the liberal vogue and how the degradation of their rights tooked place with the formation of the Brazilian national state.
\end{abstract}

Keywords: indians, city councils, political culture, independence of Brazil, citizenship. 


\section{Introdução}

Apenas seis anos separaram a independência do Brasil e a promulgação da lei de $1^{\circ}$ de outubro de 1828, uma das mais importantes medidas da transformação administrativa nacional. Foi elaborada como um desmembramento das discussões decorrentes da Constituição de 1824 e, por meio dela, as câmaras municipais perderam sua competência política e jurídica, passando a "corporações meramente administrativas"1 e fazendo com que o poder local se concentrasse nos governos provinciais (SOUZA, 1999, p. 340; SLEMIAN, 2009, p. 186-191; SOUZA, 2016, p. 247-249). Uma perda considerável se comparadas ao que eram no Antigo Regime.

As câmaras municipais representavam a base do poder da Coroa portuguesa capilarizado nos confins do seu território. Também como representação da sociedade corporativa portuguesa, as pessoas que conseguiam o direito de ocupar esses espaços, ou andar na governança, eram considerados "homens bons", ou "nobres da terra". Era na condição de vereadores, juízes ou quaisquer outros cargos que as elites de vilas e cidades poderiam relacionar-se com o rei, pedindo-lhe mercês, prestando-Ihe fidelidade e exercendo poder em suas localidades (BICALHO, 1998, p. 5-6; FRAGOSO, GOUVÊA, BICALHO, 2000, p. 70-79; GOUVÊA, 2002, p. 125-126; NOGUEIRA, 2017, p. 123-124).

As lideranças de alguns povos indígenas aliados à monarquia lusitana também conseguiram se alçar à condição de nobreza da terra com a elevação de suas aldeias a vilas pela promulgação do Diretório dos Índios (LOPES, 2005, p. 276-278). Criada para o Grão-Pará em 1757, e estendida ao restante do Brasil em 1758, a lei tinha como objetivo integrar os índios à sociedade colonial portuguesa por meio do trabalho compulsório e remunerado por aluguel, pela mudança dos costumes e pela declaração de que eram súditos livres e iguais aos outros. Ainda assim, eram considerados incapazes, o que exigia a presença de um diretor nas vilas e nas outras povoações que não haviam sido elevadas a essa condição, cuja missão era cuidar do trabalho e civilização dos indígenas (SILVA, 2005, p. 80-82). A ambiguidade do autogoverno - de serem súditos “iguais", porém, incapazes - era especialmente expressa nas câmaras municipais das vilas de índios: ao mesmo tempo que a eles se reservava cargos nos senados, também eram obrigados a dividi-los com brancos ou outros extranaturais (SILVA, 2005, p. 96-118).

A presença de não-indígenas nas povoações era prevista pela lei setecentista com o objetivo de que ajudasse na civilização dos índios, contanto que fossem garantidos o respeito por parte dos extranaturais e as prerrogativas indígenas de liberdade, propriedade e posição social. No entanto, a documentação das câmaras municipais revela o contrário: os conflitos e assédios fizeram parte da história dessas localidades, especialmente a partir dos últimos anos do século XVIII. A presença de não-índios nas vilas e câmaras aumentou no início dos Oitocentos, enquanto a população indígena decrescia principalmente pela dispersão, ou seja, a fuga das violências dos diretores para outras regiões, com raros momentos de exceção (MOREIRA, 2019, p. 278-348; COSTA, 2019, p. 43-51; COSTA, 2020a, p. 101-112). 
As vilas de índios no Ceará ${ }^{2}$ do século XIX eram Messejana (bairro em Fortaleza), Arronches (bairro da Parangaba, em Fortaleza) e Soure (atual cidade de Caucaia, vizinha a Fortaleza - Figura 1), Monte-mor Novo (atual Baturité, próxima à capital) e Vila Viçosa (atual Viçosa do Ceará, na serra da Ibiapaba, fronteira com o Piaui), e duraram até 1831, quando o Diretório entrou em desuso na província (COSTA, 2018, p. 99). Mas, poucos anos antes, as câmaras já haviam sido completamente ocupadas pelas elites extranaturais dessas localidades.

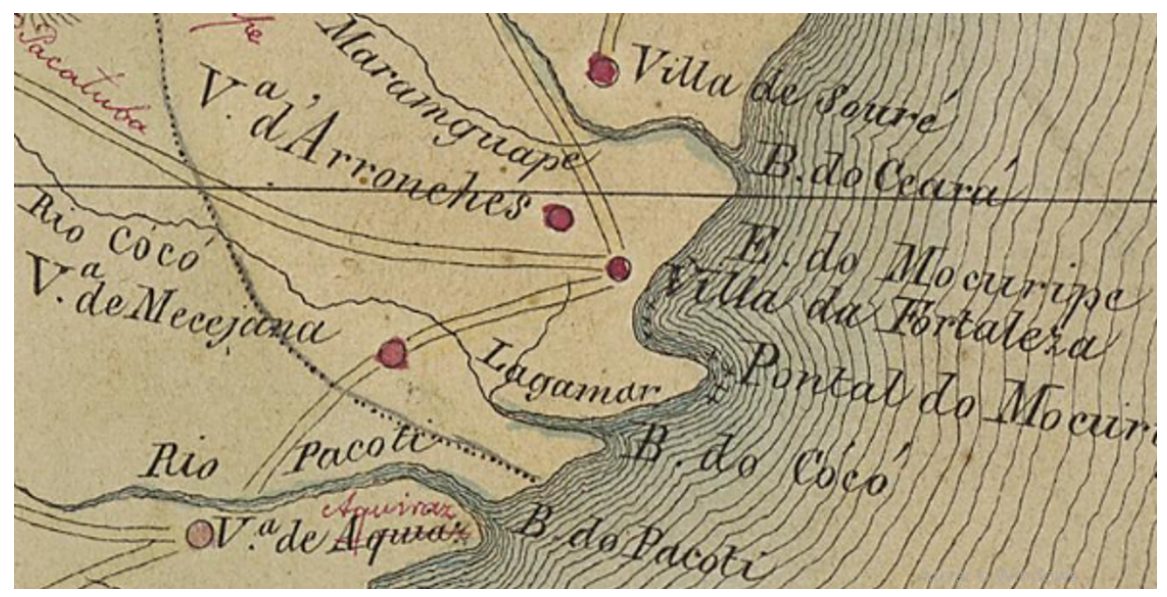

Figura 1 - Vilas de índios de Soure, Arronches e Messejana, circundando a capital do Ceará, Fortaleza.

Fonte: "Mapa da capitania do Ceará levantada por ordem do governador Manuel Ignácio de Sampaio por seu ajudante de ordens Antônio José da S. Paulet, 1818". Biblioteca Nacional, ARC. 029, 05, 023. Disponível em: http://objdigital.bn.br/objdigital2/acervo_digital/div_ cartografia/cart529227/cart529227.html. Acesso em: 5 de setembro de 2020.

O primeiro marco dessa transformação foi a seca de 1825, bastante referenciada na documentação e frequentemente utilizada como argumento nos projetos de extinção das vilas e remoção de indígenas. Foi a primeira grande estiagem a atingir as províncias do norte no novo império do Brasil, e, segundo o deputado Queiroz Carreira, o Ceará foi a mais impactada e a "mais infeliz que todas as do Império" (OLIVEIRA, 2019, p. 176). De acordo com a narrativa dos que se apossaram dos territórios indígenas, a estiagem fizera com que a população definhasse, a que sobreviveu desertasse, e, sendo poucos, não teriam condições e capacidade de cuidar devidamente das terras que, segundo as elites, já não eram mantidas antes com o zelo necessário (COSTA, 2020b). 


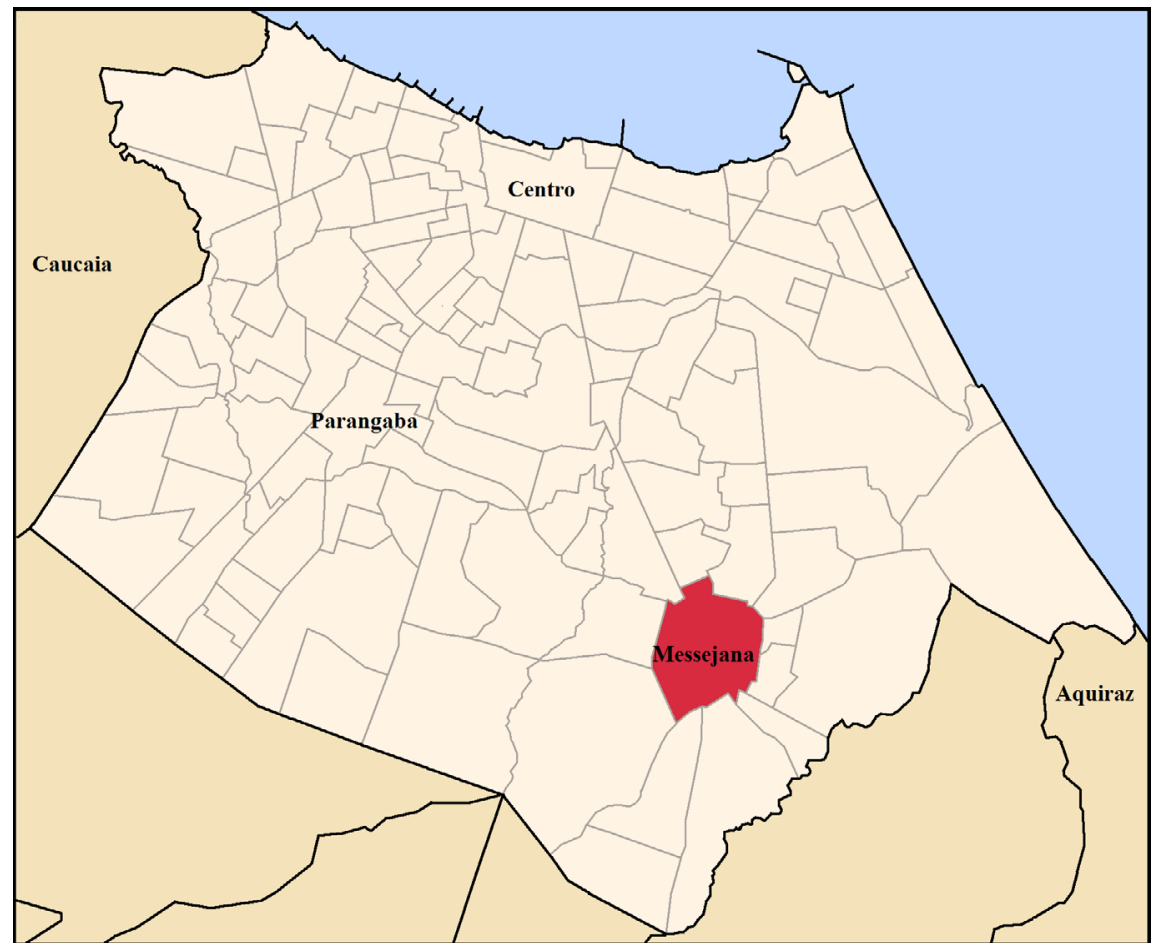

Figura 2 - Localização do atual bairro de Messejana, em Fortaleza.

Fonte: Wikipédia. Disponível em: https://pt.wikipedia.org/wiki/Messejana_(Fortaleza). Acesso em 5 de setembro de 2020.

O que se percebe é que a queda populacional, ainda que as proporções possam ter sido exageradas, não era uma justificativa plausível para que as câmaras deixassem de contar com cargos reservados para indígenas, já que não se negava que alguns continuaram a habitar as vilas. Sem ordem contrária, o Diretório continuava válido, pelo menos até a promulgação da já mencionada lei de $1^{\circ}$ de outubro de 1828 . Ainda que não citasse a normativa setecentista, a nova legislação foi fatal para os direitos políticos indígenas: confirmava a extinção do cargo de juiz municipal, instituía um critério censitário para acesso a seus postos e derrogava todas as leis anteriores que tratavam das câmaras (o que, teoricamente, atingia o Diretório). ${ }^{3}$ É a partir daí que as narrativas sobre diminuição e incapacidade da população indígena ganharam força na administração provincial e nas até então vilas de índios.

Por isso, impressiona o quão rápida foi a transformação desses espaços. Até os primeiros anos da independência, as câmaras eram instituições por excelência da agência política indígena. Por meio delas, na condição de nobres da terra, as lideranças 
poderiam cuidar da economia da vila, gerir a presença de extranaturais e lutar pela qualidade de vida dos índios. Ainda que também atuassem como representantes da Coroa na civilização dos seus subordinados, também recebiam queixas e requerimentos individuais ou coletivos contra diretores e proprietários, levando suas representações aos governos da capitania e província ou à própria Coroa. Lutavam por sua comunidade, por seu patrimônio e pela incolumidade de suas propriedades, liberdade e posições (MAIA, 2010, p. 244-265; MOREIRA, 2019, p. 264-277; COSTA, 2019; COSTA, 2020a, p. 101-108). Apesar de defenderem as prerrogativas garantidas no Diretório, inclusive no contexto liberal pós-1822, também iam de encontro à lei por entenderem-se plenamente capazes de autogoverno. Todas essas características da cultura política indígena podem ser analisadas na documentação das atas de vereação das câmaras municipais, como é o caso da de Messejana (Figura 2), foco deste estudo por ser a mais bem preservada dentre todas as vilas de índios do Ceará.

No entanto, o conteúdo das mesmas se transformou perceptivelmente depois de 1828. Há confusões de conciliação entre a lei das câmaras e o Diretório, curiosamente ainda em vigor no Ceará, e referências a perdas de terras em tom piedoso aos índios usurpados, apesar de apontá-los como intelectualmente limitados, o que indica a efetivação de sua exclusão. Pensando nessa curta, intensa e trágica trajetória, analisemos a seguir o impacto da formação do Estado nacional brasileiro nos direitos políticos indígenas a partir da câmara municipal da vila de índios de Messejana. Nos serviremos de fontes produzidas em sua maioria no âmbito da vila, buscando perceber as características da cultura política indígena em meio ao liberalismo nos anos 1820 e a espoliação sofrida ao final da década.

\section{Os índios vereadores na câmara municipal de Messejana e o advento liberal}

A presença obrigatória de brancos sempre foi motivo de tensões nas vilas de índios. A pretensa igualdade prevista no Diretório ${ }^{4}$ era utópica na medida em que não havia súditos iguais aos outros no Antigo Regime. A hierarquização era intrínseca às relações sociais coloniais e, por isso, os extranaturais dificilmente tratariam os índios com o respeito devido. Os choques iam desde o simples escárnio - como o registrado por Henry Koster (2003, p. 177) - até as violências praticadas por proprietários e diretores no usufruto da força de trabalho e as ocupações indevidas das terras indígenas nos termos das vilas (ou seja, o território municipal). A própria figura do diretor, idealizada com a missão de proteger e civilizar, era muitas vezes caracterizada pela barbárie nos seus procedimentos por representantes indígenas e pela administração imperial. Por meio das câmaras municipais, os índios vereadores e oficiais de ordenança buscavam por muitas formas coibir as agressões, mas pouco poderiam fazer naquilo que não Ihes competia, como a organização do trabalho indígena. De toda forma, era por esses espaços que as lideranças levavam as queixosas vozes dos índios às instâncias superiores à espera de ações concretas e protetoras de suas prerrogativas.

O governo de Manuel Ignácio de Sampaio foi um período de exceção, cujos efeitos no cotidiano das vilas se fizeram sentir. Apesar de absolutamente rigoroso na disciplina militar, na organização do trabalho dos índios e na luta aguerrida contra 
a "vadiagem" por meio da "polícia de passaportes", Sampaio combateu ferozmente as agressões e a falta de pagamentos que frequentemente sofriam as comunidades (COSTA, 2015, p. 133-150). As lideranças indígenas reconheciam positivamente a postura do governador, posicionando-se como mediadores exemplares entre os anseios dos liderados e os da Coroa. Ou seja, desejavam tanto a preservação da dignidade de seus povos quanto o cumprimento das premissas civilizatórias projetadas pela monarquia. Um exemplo impressionante foi a carta de despedida escrita pela câmara de Messejana a Manuel Ignácio de Sampaio, quando deixou a liderança da capitania do Ceará em 1820 para assumir em Goiás, a quem "chama[vam] mais nosso pai que governador". Intitulavam-no também de "nosso benfeitor [...], o protetor de verdade, da justiça e da inocência [...], nosso herói”, por "promover a felicidade dos habitantes em geral sentando com a maior imparcialidade o direito individual”. Objetivamente, os repúblicos ${ }^{5}$ de Messejana se sentiam gratos por Sampaio tê-los feito

\begin{abstract}
civilizados neste giro do correio, o que são preferidos, a pronto pagamento de seus jornais, e de seus filhos, que alguns brancos pretendem negar-lhes, e que conhecida a verdade, as faz pagar prontamente, a proibição de se darem índios para as vilas longe das aldeias, a que nunca mais tornavam, e por isso hoje as aldeias estão muito aumentadas em população, não só por este princípio, como pela escolha que faz das pessoas para diretores...6
\end{abstract}

Por esse posicionamento, os membros da câmara de Messejana cumpriam aquilo que projetava a Coroa com o Diretório: o comprometimento na civilização indígena por meio do trabalho e da igualdade enquanto súditos. Seria ingenuidade acreditar que todos os índios das povoações concordavam com isso, ou mesmo não suspeitar de que o floreio das palavras utilizadas não passava de estratégia discursiva em prol da própria imagem perante as autoridades. Mesmo assim, não se pode negar o apreço dos índios a questões muito concretas, como bom tratamento e remuneração (COSTA, 2018, p. 326-327). Para as lideranças da vila, a "civilização" de seu povo não se dava simplesmente pela mudança de costumes e submissão a uma cultura dita superior. Como aponta Isabelle da Silva, "admitir a ignorância e a possibilidade de superá-la", por parte dos índios, significava o reconhecimento do "próprio não enquadramento" a um sistema que os submetia e violentava (SILVA, 2005, p. 128). Sua postura perante o governador revela seus anseios pela igualdade prevista na lei materializada em dignas relações sociais e de trabalho, que gerou, como resultado, o crescimento da população nas povoações de índios no Ceará ao final da década de 1810.

Percebe-se que os indígenas não necessariamente se opunham ao trabalho (MOREIRA, 2012, p. 241). Ao contrário, possuíam uma concepção própria acerca da gestão do espaço da vila, da produção e dos serviços a serem prestados ao Estado ou a particulares. Também não se tratava de uma única concepção: cada comunidade, com suas respectivas lideranças, tinha seus próprios projetos baseados em experiências e culturas políticas específicas. Por exemplo, os índios de Viçosa, na serra da Ibiapaba, produziram, em 1814, um longo requerimento pedindo a abolição do Diretório, a 
expulsão dos brancos, a devolução das terras e o envio de mantimentos que seriam pagos com algodões em plumas (XAVIER, 2010, p. 76-105; COSTA, 2018, p. 74-81, 128137). Em 1816, lideranças indígenas de Messejana pediram ao governador da capitania que impusesse penalidades a quem soltasse gado sobre as lavouras dos índios no Cambeba, para que, assim, pudessem plantar em paz. Segundo eles, a agricultura se conduzia de forma proveitosa até a chegada de vizinhos e suas criações (COSTA, 2018, p. 273-275; COSTA, 2019, p. 45). As duas perspectivas indígenas diferiam nas ambições, indo da tentativa de convivência até o banimento dos forasteiros. Contudo, o que as unia era a certeza de que o desenvolvimento da produção e, consequentemente, da civilização por meio do trabalho, tão almejados pelo Diretório, eram inviáveis enquanto os índios continuassem dependentes da tensa convivência com os extranaturais e limitados em comparação a eles na sua liberdade.

A busca por autonomia encontrou espaço com o advento do liberalismo em território lusitano, com a Revolução do Porto, a convocação das Cortes de Lisboa e as discussões sobre a Constituição portuguesa. Julio Sánchez Gómez analisou representações de indígenas dirigidas à Assembleia Constituinte em 1821 sobre mudanças legais, liberdade de comércio e queixas contra maus-tratos (2009, p. p. 250-251). Segundo André Roberto Machado, a luta por garantias constitucionais fez parte das prioridades das comunidades indígenas inseridas nas discussões desse contexto (2006, p. 108). Para isso, a atuação dos índios não se restringia à defesa do que já tinham, mas também se dava no sentido de ampliar suas prerrogativas, como foi o caso das lideranças de Monte-mor Velho, que submeteram um memorial na câmara de Aquiraz em janeiro de 1821 - poucos dias antes do início dos trabalhos das Cortes de Lisboa -, solicitando que pudessem viver sem diretor (COSTA, 2018, p. 124). Portanto, a conjuntura constitucional era vista como um momento de oportunidades.

Nesse mesmo contexto, os membros do senado de Messejana enviaram à Junta Governativa do Ceará, em janeiro de 1822, um memorial com sugestões para a vila, e com o que achavam "mais conveniente ao melhoramento e bem do público e da província". Elaboraram-na em resposta a um ofício da Junta de novembro do ano anterior e em conjunto com os "demais cidadãos", assinada pelos vereadores Joaquim Lopes de Abreu Lage, Lourenço Soares da Costa, Antônio Francisco Pereira e Francisco Pereira Correa Lima. ${ }^{7}$ O primeiro era português e conhecido ocupador de terras da serra de Maranguape, algumas delas indígenas. ${ }^{8}$ Não encontrei referências acerca do segundo, e os dois últimos eram índios. ${ }^{9}$

Mesmo dividindo os cargos da câmara com extranaturais pela exigência de composição etnicamente mista do Diretório, os índios presentes não deixavam de imprimir sua autoria nas demandas. De acordo com José de Souza Azevedo Pizarro e Araújo, Messejana contava com muitos moradores brancos em seu termo, mas a maioria eram índios que "se emprega[vam] no serviço dos povoadores da Fortaleza". Entre 1811 e 1821, a população havia quase dobrado, chegando a cerca de 3 mil pessoas (ARAÚJO, 1822, p. 234), o que indica um significativo crescimento dos indígenas somado à intensa imigração de extranaturais. Tendo sido o memorial escrito com a presença de outros moradores da vila, é presumível o peso considerável da vontade 
dos extranaturais na produção do texto, mas não descartava a provável prevalência dos índios. Chama a atenção também o fato de se referir aos habitantes da vila enquanto cidadãos, indicando que os índios também assim se enquadravam e já se apropriaram do linguajar liberal, o que será confirmado na análise pormenorizada dos capítulos do memorial.

Segundo Mariana Dantas, assumir-se simultaneamente cidadão e indígena era circunstancial, sendo importante para alguns grupos e indivíduos a depender do contexto (2018, p. p. 169-170). Mas é possível que mais pesquisas sobre os senados das vilas de índios revelem que tais identificações foram mais comuns do que se imagina. Desde a formação das Juntas de Governo Provinciais com a eclosão do constitucionalismo na América portuguesa, período em que se criaram "possibilidades e expectativas de transformação da ordem política” (SLEMIAN, 2009, p. 73), as câmaras municipais serviam como "lugar de aprendizado político e espaço de negociação dos interesses diversos” (SOUZA, 1999, p. 118), inclusive nas vilas de índios. Por exemplo, o caso que analisamos se tratava de uma ação comunitária que reivindicava a múltipla condição de índios, súditos, cidadãos, livres e capazes, além da posse da terra coletiva baseada em garantias municipais originárias do Antigo Regime, como veremos mais à frente. Se índios já eram incluídos na lista de eleitores para deputados das Cortes de Lisboa em 1821, como mostra Raquel Santos sobre o Grão-Pará (2013, p. p. 63-67, 80), não surpreende que a cidadania tenha sido operacionalizada pelos indígenas no âmbito da câmara de Messejana já no início de 1822.

O memorial é composto de oito capítulos e trata de temas variados, como produção agrícola, infraestrutura, comércio, tributação, rendimentos da câmara, trabalho, tutela e educação das crianças. A agricultura é abordada já no primeiro capítulo. Segundo os autores, a atividade era um dos

\begin{abstract}
principais objetos para aumento da província e as terras desta vila e seu termo é um dos lugares bons da comarca para a agricultura a qual não se pode bem estabelecer pela falta de possessões dos moradores por não terem fábricas [ajudantes]. Acordaram com o voto de todos [que] se devia pedir e requerer viessem escravos para se venderem aos moradores e que estes seriam pagos com os frutos das mesmas lavouras e plantações que se fizesse e a pagamentos anuais. ${ }^{10}$
\end{abstract}

A indicação de acordo coletivo no primeiro capítulo se repete nos outros, o que confirma que o memorial da câmara foi elaborado em conjunto com outros membros da comunidade, e que suas características e pretensões não se referiam exclusivamente ao pensamento das lideranças políticas da vila. Mas o mais importante é a forma como os indígenas se percebiam por meio das relações de trabalho. Na nova ordem liberal, se colocavam como cidadãos-súditos iguais aos outros, na medida em que também poderiam se servir de escravos pagos pela própria produção. Tão escassa quanto a bibliografia a respeito da cidadania indígena no início do Império é aquela referente a indígenas donos de escravos nesse contexto, ou ao que o direito de possuí-los representava no repertório político dos índios, necessitando de discussões mais 
profundas. Por ora, resta afirmar que, nesse aspecto, os indígenas de Messejana rompiam com a lógica do Antigo Regime quando só tinham condições de servir alguém, seja por sua qualidade inferior ou porque a vida imposta pelo Diretório impedia que a grande maioria dos índios acumulasse possessões.

A câmara e o povo entendiam que a agricultura poderia se desenvolver com o incentivo do governo da província, mas o esforço seria em vão se o território de Messejana fosse dividido entre outros municípios que o ambicionavam. No capítulo 4, argumentaram que a vila deveria continuar com o mesmo termo de quando foi criada em 1760

sem que as justiças da vila da Fortaleza e Aquiraz se intrometam nela, porque é de utilidade pública e conveniente aos povos tanto no juízo eclesiástico quanto no secular. Acordaram uniformemente que deveria ser mais para o termo desta vila da barra do rio Pacoti por ele acima até a barra do rio Tapuiú, e por este acima até as Cajazeiras, ribeira do Pacoti, subindo pelo riacho da Guaiúba até o cume da serra da mesma Guaiúba, e daí frechando direito a ponta da serra Pitaguari da parte do nascente, e daí rumo direito à barra do Cocó, e que este mesmo termo seria útil e benéfico dos povos, cujo termo seria e ficaria sendo freguesia. ${ }^{11}$

A vontade do povo de Messejana ia no sentido oposto à ideia corrente de que as vilas e freguesias de índios deveriam ser extintas porque suas terras seriam subaproveitadas, tendo mais serventia se fossem repartidas por outros proprietários por meio das câmaras das vilas vizinhas. Ao contrário, entendiam que o desenvolvimento só seria possível com a preservação das terras que tão bem conheciam, fundamental para a autonomia tanto do âmbito sagrado quanto do produtivo. Pelo Diretório, no ato de fundação das vilas, seus termos eram divididos e demarcados os patrimônios da câmara - "legalmente justificada pela necessidade de conservação e subsistência da mesma, o que se daria através do pagamento do foro dos então constituídos enfiteutas" -, dos oficiais, dos extranaturais - que pagariam foro ao senado -, dos índios - isentos de foro - e as áreas de uso comum indígena (SILVA, 2005, p. p. 117119). A luta pela conservação da posse fundiária de Messejana já vinha de alguns anos e marcou a mobilização indígena por meio da câmara municipal durante o início do século XIX (COSTA, 2019, p. 43-47).

A cartografia da época revela as confusões dos limites territoriais municipais e o avanço de Fortaleza e Aquiraz sobre as terras das vilas de índios que circundavam a capital. Como vemos a seguir no detalhe do "Mapa da Capitania do Ceará", de 1818 (Figura 3), a identificação dos termos das vilas de Fortaleza e Aquiraz ultrapassavam geograficamente a localização das vilas de índios de Soure, Arronches e Messejana, situadas ao redor da capital cearense. Encomendada pelo governo da então capitania, o mapa registra localidades mencionadas no memorial de Messejana, como os rios Guaiúba, Pacoti e Cocó. Ou seja, se nem mesmo a cartografia fazia referência aos termos dos municípios indígenas, as autoridades das vilas de brancos também não 
respeitavam as posses das terras dos índios, demarcadas em meados do século XVIII com a promulgação do Diretório.

Além de reclamações sobre invasão de gado em plantações, como a que vimos anteriormente, em 1812, a câmara de Fortaleza tentou se apossar das serras da Monguba (atualmente terra indígena da etnia pitaguari), o que provocara a reclamação do senado de Messejana ao governador Sampaio no mesmo ano (COSTA, 2019, p. 47-49). Segundo os repúblicos, a região era importante por ser onde havia produção agrícola e talhos para o arremate do contrato de carne verde, sem o qual "por infalível padecerão os povos desta vila à falta deste gênero das carnes, um dos da primeira necessidade de que se não pode passar sem ele".12

Para os vereadores de Messejana, a integridade do patrimônio fundiário da vila era condição essencial para o abastecimento e qualidade de vida da população por meio do comércio, cujo pleno desenvolvimento era tema importante e presente em outros capítulos do memorial. No $6^{\circ}$, sugeriram a construção de pontes nos rios Cocó e Tamatanduba, "que no tempo do inverno imped[iam] a passagem dos viandantes e do comércio para esta província".13 O "aumento" da vila de índios, em benefício de seus habitantes, seria consequência da junção da preservação do território com o apoio do governo da capitania, pelo já mencionado envio de escravos ou por investimentos em infraestrutura.

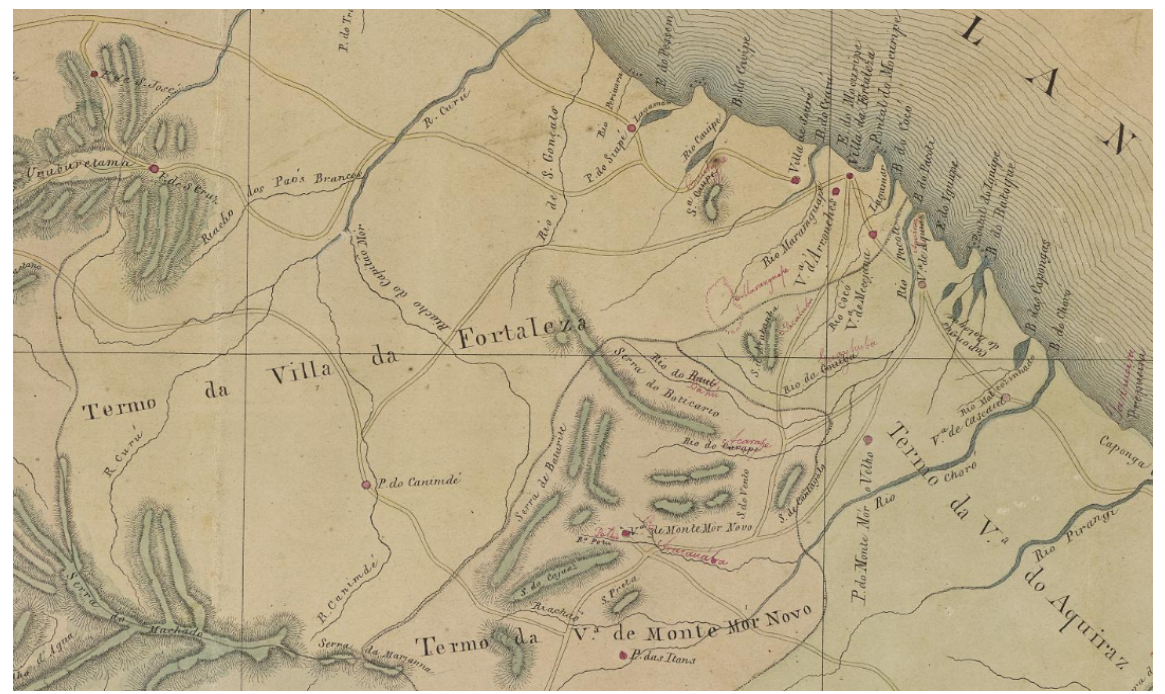

Figura 3 - Vilas de índios e termos de Fortaleza e Aquiraz.

Fonte: "Mapa da capitania do Ceará levantada por ordem do governador Manuel Ignácio de Sampaio por seu ajudante de ordens Antônio José da S. Paulet, 1818". Biblioteca Nacional, ARC.029, 05, 023. Disponível em: http://objdigital.bn.br/objdigital2/acervo_digital/div_ cartografia/cart529227/cart529227.html. Acesso em: 5 de setembro de 2020. 
Os aportes governamentais para o desenvolvimento comercial também são tema do quinto capítulo. Segundo os autores do memorial, a "razão de padecerem os povos desta vila e seu termo faltas de carne no açougue para sua subsistência era o subsídio e novo imposto que se pagam sobre as carnes verdes". Decorria que não havia "com abundância as ditas carnes, com grave prejuízo do povo, em consequência de serem por alto preço" e, por isso, sugeriam "que se devia abolir este tributo por ser gravoso". Outro resultado da situação foi descrito no capítulo 8, em que relataram que a "câmara não t[inha] rendimento algum para poder ter alfaias e obras precisas porque algum pequeno rendimento que tenha era do contrato das carnes, [e] este já não há quem remate e nem pessoa que queira matar rês alguma". Daí a necessidade de "que se deveria estabelecer algum suficiente rendimento para a câmara". ${ }^{14}$

O assunto era um antigo problema para as vilas de índios, e fora tratado pelo ouvidor Manuel de Magalhães Pinto e Avelar por ocasião da visita a Soure, Arronches, Monte-mor Novo e Messejana em 1786. Tentou relacionar a pobreza das câmaras com as determinações sobre o comércio de carne nessas povoações e os impostos cobrados. ${ }^{15}$ A questão também fora abordada pelo secretário de governo do Ceará, José Rabelo de Souza Pereira, em 1815, que também compreendia que o imposto encarecia o produto, inviabilizava o comércio e provocava a migração de índios para o Piauí. ${ }^{16}$ Em 1822, a tributação acabava não tendo proveito para as rendas da câmara de Messejana porque, pela pobreza dos habitantes, impossibilitava o comércio ameaçado pela ambição fundiária de outras vilas - e, consequentemente, a acumulação pelo conselho. Portanto, a proposta dos repúblicos e do povo da vila de índios era sofisticada, já que previa a subsistência dos moradores associada à manutenção da câmara que conseguiria arrecadar os tributos de uma economia viável.

O assunto também foi abordado no terceiro capítulo. Segundo os membros do senado, o mercado não se desenvolvia na vila "por não se poder vender nela licores espirituosos, que é um dos gêneros de negócio que faz aumentar o mesmo comércio, por ser este gênero proibido na conformidade do Diretório". Por isso, pediram "que neste particular ficasse o dito Diretório abolido por resultar em benefício público". ${ }^{17} \mathrm{~A}$ proposta era mais ousada porque envolvia a mudança de uma tradição de décadas na política indigenista no Ceará. A lei setecentista sobreviveu à Carta Régia de 1798 (que não teve nenhum efeito em território cearense), teve sua permanência defendida no século XIX por administradores coloniais e atravessaria a independência, pelas características econômicas, demográficas e estratégicas da região (XAVIER, 2015, p. 99-100; COSTA, 2018, p. 47-96). Ainda assim, o memorial de Messejana justificava sua demanda com o desenvolvimento comercial, uma questão que interessava tanto aos habitantes da vila quanto aos governos da província e do império.

Além disso, aproveitavam o período constitucional e liberal que vivia o mundo português. Identificando-se enquanto cidadãos no ofício em que as propostas foram em anexo, os índios demarcaram certa ruptura com o Antigo Regime, quando sua condição de súditos livres e "iguais aos outros" era limitada por serem ainda considerados incapazes. De acordo com Lúcia Pereira das Neves, durante as discussões das Cortes em Lisboa, a "prática liberal considerava a igualdade perante a lei como condição 
inerente ao cidadão, dando uma nova conotação ao exercício da cidadania", com exceção dos escravos. Apesar de determinados setores, como alguns membros da imprensa, excluírem "as camadas mais ínfimas da sociedade luso-brasileira”, os índios de Messejana tanto se contrapunham a essas ideias quanto subvertiam o próprio Diretório, ao se apropriarem da cidadania nos sentidos de "maioridade política" (NEVES, 2003, p. 181-183) e de capacidade. O pedido de permissão para comercializar bebidas alcoólicas indica que viam nesse contexto a oportunidade de não mais se sujeitarem à categorização que os relegava a uma "qualidade" inferior.

Também buscaram alterar a hierarquia do Antigo Regime no capítulo 7, quando disseram que "os índios desta vila não queriam ter diretor, que deveriam ser administrados debaixo da inspeção do seu respectivo capitão-mor e que estes seriam obrigados a trabalhar aos moradores, mas que seus filhos não seriam tirados para o trabalho e serviço dos moradores como dantes eram obrigados". ${ }^{18}$ A rigor, seria contraditória a manutenção da tutela prevista no Diretório com a condição da cidadania. De acordo com a lei setecentista, as vilas e povoações indígenas deveriam ser conduzidas por um diretor, substituto dos antigos missionários religiosos responsável pela vigilância dos índios em relação aos costumes, à distribuição no trabalho de aluguel a proprietários e governos e à remuneração. A historiografia sobre o Diretório aborda largamente os costumeiros embates entre índios e diretores, muitas vezes acusados de abusos, violências, aproveitamento individual e despreparo (LOPES, 2005, p. 251-254, 269271; SILVA, 2005, p. 157; MAIA, 2010, p. 293-294).

Os índios de Viçosa que pediram a anulação do Diretório em 1814 embasaram sua solicitação no histórico de tensões entre os diretores que passaram pela vila e na povoação de Baepina. Entendiam que a presença dessas figuras, e dos brancos em geral, era danosa para a comunidade e infringia a própria lei que os declarava súditos livres e iguais aos outros e merecedores de bom tratamento. ${ }^{19}$ Já os vereadores e o povo de Messejana não foram tão longe porque, da mesma forma que o pedido dos índios de Viçosa e Baepina fora negado, dificilmente seria acatada uma proposta que almejasse o fim do trabalho compulsório e abdicasse da força de trabalho indígena. Agindo após a experiência da Ibiapaba, a sugestão de troca dos diretores por capitãesmores índios buscava, portanto, conciliar interesses.

Isso mostra que a ruptura com o Antigo Regime na cultura política dos índios de Messejana, no início de 1822, não era completa. Como revelam outros estudos, as tradições e experiências que remetiam ao período anterior à independência e ao liberalismo continuaram a conduzir posicionamentos e decisões indígenas por muitos anos no início do século XIX (ALMEIDA, 2007, p. 204-205; COSTA, 2018, p. 106-110, 356-380; MOREIRA, 2019, p. 331-333). No caso que analisamos, a capacidade cidadã de comercializar licores espirituosos continuaria convivendo com a condição tutelar, mas em um sentido novo, flexível, indígena. Não deixaram de pedir o fim da tutela por se acharem incapazes, mas porque conheciam bem as regras do jogo e os limites das mudanças pelas quais passavam as sociedades do império português. No entanto, assim como os de Viçosa, agiram em busca de autonomia, anseio presente ao longo 
de todo o memorial, seja na questão da terra, do comércio ou da administração do trabalho.

A proposta de troca dos diretores pelos próprios capitães-mores também nos ajuda a refletir sobre o papel das lideranças militares na cultura política indígena. Os oficiais de ordenança dos índios eram protagonistas no processo de enobrecimento e hierarquização promovido pela Coroa portuguesa desde o início da colonização. Com o Diretório, essas autoridades permaneceram com a missão de ser intermediários entre as expectativas da Coroa e as demandas de suas comunidades. Ou seja, a autoridade dos oficiais de câmara e ordenança indígena era sempre uma via de mão dupla, já que, junto do reconhecimento da Coroa, necessitavam da aceitação de seus comandados (LOPES, 2009; MAIA, 2010, p. 277-292; COSTA, 2018, p. 247-254). Além disso, ainda nesse período, a escolha de quem receberia patentes de ordenança era das câmaras municipais (COSTA, 2018, p. 254-255). Por exemplo, "achando-se vago o posto de sargento mor e dois capitães do terço de ordenança” de Messejana, em dezembro de 1820 , os vereadores foram incumbidos pelo governador da capitania de "fazer proposta para os ditos postos vagos" ${ }^{20}$ Se tais oficiais militares indígenas substituíssem os diretores, como propunha o povo de Messejana, o poder político municipal estaria ainda mais concentrado no senado da vila. Mais uma vez, a autonomia aparece efusivamente nas propostas de administração urbana e do trabalho, que continuaria sendo obrigatório.

Com isso, procurava-se garantir o desenvolvimento econômico da vila aliado à qualidade de vida de seus habitantes por meio de um autogoverno pleno, onde a fiscalização dos moradores e a gestão da terra, do comércio e do trabalho seriam feitas pelas próprias lideranças, cuja autoridade era fundamentada no reconhecimento da comunidade. Com mais controle do próprio cotidiano, os índios teriam mais força para combater abusos e manter suas prerrogativas por tempos futuros, desejo perceptível nas sugestões relativas às crianças indígenas. Reclamações acerca do trabalho infantil, como a que vimos no capítulo 7 do memorial, são recorrentes em outras representações dos índios no Ceará sob a vigência do Diretório, indício de que o tratamento enquanto "súditos iguais" por parte de proprietários era frequentemente desrespeitado (MAIA, 2010, p. 309; XAVIER, 2010, p. 67). Para cessar de uma vez tal relação de escravidão velada com as crianças, a câmara de Messejana complementou o pedido de fim do seu trabalho e requereu investimentos para educação. No segundo capítulo, disseram que "a mocidade, em razão de não ter mestre das primeiras letras que os ensinem, se tem criado até agora [...] sem aprender a ler, escrever e contar, e sem domínio algum", e, por isso, expuseram "que deveria haver um mestre régio para a educação da dita mocidade, e igualmente mestra" ${ }^{21}$

A falta de professores exposta pelos repúblicos de Messejana era problema antigo nas vilas pombalinas, que foi registrado até o início do século XIX, e destoava bastante do que o Diretório ainda em voga projetava (SILVA, 2005, p. 129-131; LOPES, 2005, p. 478-479). Na lei, era obrigatório que todas as povoações e vilas de índios tivessem escolas que ensinassem aos meninos e às meninas as primeiras letras, a matemática, a doutrina cristã e os ofícios concernentes a cada sexo. No início da aplicação, foram 
enviados a Portugal registros da evolução da educação das crianças das vilas de índios do Ceará e do Rio Grande do Norte, com pequenos textos e exemplares de bordados feitos por estudantes indígenas, analisados por Fátima Lopes (2005, p. 468-474). Para bancar a manutenção das escolas e pagamento dos e das mestres, foi criado no Ceará o imposto "subsídio literário" que insidia sobre o comércio de carnes. O encarecimento do produto provocou deserções de índios das vilas e povoações, como vimos anteriormente, mas também muitas reclamações por escrito possibilitadas justamente pelos investimentos em educação. "Como vemos, curiosamente, as carnes e as letras andavam de mãos dadas no cotidiano dos índios no Ceará na passagem dos séculos XVIII e XIX" (MAIA, COSTA, 2018).

Alguns governos se preocuparam com a educação: um ano antes da produção do memorial, o governador Rubim intimou o capitão-mor indígena de Messejana, Atanásio Faria Maciel, que "obrig[asse] os índios de sua vila em idade de ir à escola para que os mande na forma do Diretório", com pena de serem dados "de aluguel a quem os quiser como até agora se praticara". ${ }^{22}$ Rubim foi deposto em novembro de 1821 pela Junta Provisória fiel às Cortes de Lisboa (ARAÚJO, 2018, p. 88) e, em janeiro de 1822, vereadores e povo de Messejana já reclamavam da falta de professores no memorial que analisamos. É difícil saber se no tempo do antigo governador já havia falta de mestres, apesar da intimação que emitiu, ou se a Junta deixou de contratá-los. De qualquer maneira, o memorial mostra que a preocupação das autoridades coloniais com a educação das crianças indígenas, com fins de que se educassem com os costumes cristãos e portugueses (LOPES, 2005, p. 474; MAIA, 2010, p. 258), também era importante para os índios vereadores, pois garantia a manutenção de uma elite indígena letrada que poderia ocupar os cargos de câmara e mais habilmente atuar em benefício de suas comunidades (SILVA, 2005, p. 136-137). O "fascínio da escrita”, comentado por John Monteiro (2001, p. 77), tinha aplicação prática nas vilas de índios e explicava a importância central do ensino das crianças.

Em julho de 1822, a Junta Provisória do Ceará nomeou João da Costa Pontes para o "emprego de professor de $1^{\mathrm{a}} \mathrm{s}$ letras da vila de Messejana, com o qual vencerá o ordenado de 150\$00r\$ anuais, e será obrigado a prestar juramento à câmara respectiva". ${ }^{23}$ Pelo menos acerca da educação, os vereadores foram atendidos, mas, sobre as outras demandas do memorial, não encontrei respostas da Junta Provincial. De fato, muitas das propostas eram audaciosas, mas o silêncio do governo se devia à relação tensa que estabelecia com os índios à época. Os membros que compunham a Junta Provisória eram oriundos das elites econômicas de Fortaleza e Aquiraz, partidários das Cortes de Lisboa e sedentos pela exploração da mão de obra indígena (ARAÚJO, 2018, p. 95-110). Os índios, por sua vez, viam-nos como os que subjugaram o rei dom João VI e apoiaram a volta forçada do monarca para Portugal, considerado como entidade protetora por excelência. Por isso que também se opunham ao constitucionalismo português, o que mostra que a adequação de uma linguagem liberal por parte de uma comunidade indígena não significava sua adesão plena ao liberalismo. Ao contrário, tal operacionalização se dava por uma cultura política ainda fortemente amparada no Antigo Regime, já que era a base da expectativa de mercês do rei. Explica-se, portanto, o apoio que os índios do Ceará deram às elites do 
interior da província, que destituíram as lideranças da capital em dezembro de 1822 e declararam apoio absoluto a dom Pedro I. Para os índios, na ausência de Dom João VI, seu filho era o rei que ficara (COSTA, 2018, p. 151-157, 287-296).

A situação se embaralhou a partir da ação despótica do novo monarca com o fechamento da Assembleia, em 1823, a promulgação da Constituição de 1824 e seu famigerado poder moderador. Os membros do governo do Ceará, que havia poucos meses marcharam por Dom Pedro I, agora o viam como um tirano e aderiram à Confederação do Equador, conseguindo o apoio dos índios (COSTA, 2018, p. 329354). Percebe-se que a prioridade indígena, mais do que sua histórica lealdade ao rei, eram as prerrogativas que dele emanavam: terra, liberdade e autonomia - ou, como diz Vânia Moreira, propriedade, liberdade e autogoverno (MOREIRA, 2019, p. 149). A relação do governo rebelde cearense foi de bastante proximidade com as câmaras de vilas de índios, como se vê no agradecimento do presidente Tristão Gonçalves "às expressões de amizade" que recebeu dos vereadores de Arronches, em julho de 1824. ${ }^{24}$

Debelada a Confederação em outubro, os índios não tiveram outra alternativa a não ser prestar fidelidade a Dom Pedro I. Após a derrota dos aliados, as comunidades indígenas passaram a enfrentar dificuldades sem precedentes nos anos seguintes, sendo afetados fatalmente seus direitos políticos e, consequentemente, a sobrevivência dos cargos nas câmaras municipais.

\title{
Exclusão política indígena e a formação do Estado nacional
}

A seca que assolou o Ceará em 1825 foi especialmente violenta para as comunidades indígenas. Há muitas referências na documentação de que os índios foram os mais afetados, com alta mortandade e deserção. Segundo o padre Francisco Gomes Parente, na povoação de índios de Almofala, "pela deserção para os seus lares e mortandade no ano de 1825, não existiam mais que 5 ou 6 casais". ${ }^{25}$ De acordo com a câmara da até então vila de índios de Monte-mor Novo, a estiagem

\begin{abstract}
devorou não só o cabedal dos habitantes da província, como que diminuiu pela fome, e males que ela costuma arrastar, quase metade dos seus mesmos habitantes, e entre eles, a gente que mais pereceram foram os índios, e outras pessoas de igual condição, sempre dominados com todas as épocas da ociosidade. Enfim, os índios desta vila acabaram-se às garras da cruel fome. Que dolorosa lembrança! Apenas existe destes, entre machos e fêmeas, o número de quinze pessoas. ${ }^{26}$
\end{abstract}

Ainda que os números ou a dimensão da dispersão tenham sido exagerados com fins políticos, o impacto revela a precariedade material em que viviam os grupos indígenas. Como argumentou Fátima Lopes, as próprias exigências do Diretório aos índios, como dedicarem boa parte de seu tempo a trabalhos de aluguel, inviabilizava uma produção agrícola mínima que os sustentasse (LOPES, 2005, p. 422-428), o que se agravava em períodos de estiagem como a de 1825. Para os que sobreviveram, a fuga para regiões onde os olhos vigilantes dos diretores não os alcançassem 
poderia ser uma saída, provocando, em contrapartida, o desmantelamento desses povoados enquanto "aldeias" indígenas. Aliado às antigas acusações de inviabilidade das vilas de índios por sua alegada indolência e incapacidade, o esvaziamento das povoações provocado pela seca virou motivo para várias propostas de extinção dessas municipalidades ou deslocamento das reduzidas comunidades ainda existentes.

Tais ideias não eram novas: João Antônio Rodrigues de Carvalho sugerira em 1816 que, pelas condições precárias de Messejana, "seria melhor extinguir a denominação de vila e unir a povoação à vila da Fortaleza” (1929, p. 17). Em 1824, o diretor de Vila Viçosa, Paulo Fontenele, sugeriu desaldear os índios (XAVIER, 2015, p. 99). Com os efeitos demográficos da seca nas povoações indígenas, as propostas de extinção de suas municipalidades retornaram com mais ênfase. De acordo com Gabriel Oliveira, a seca de 1825 foi artifício para que as províncias atingidas solicitassem donativos e "pleiteassem um lugar no quebra-cabeça político do Império" nesse contexto de formação do Estado brasileiro (OLIVEIRA, 2019, p. 162), mas também embasou as argumentações de que as vilas de índios deveriam ser abolidas. Uma memória presente na Biblioteca Nacional, sem autoria ou data - mas, provavelmente, escrita pouco depois de 1825 -, sugeriu que fossem extintas "as vilas e freguesias de Messejana, Arronches e Soure", porque "foram abandonadas pelos índios, e que fiquem adjudicadas e filiais da freguesia e termo da cidade que estão encravadas na distância de uma a três léguas". Segundo o texto, era em Maranguape e na povoação de Guaiúba que "esta[vam] situados os índios que abandonaram as vilas e freguesias de Messejana, Arronches e Soure". ${ }^{27}$

Ideias semelhantes foram dadas pelas autoridades cearense em resposta à demanda da Corte que projetava a criação do Plano Geral de Civilização dos Índios, em 1826. Em setembro, o Conselho Provincial do Ceará sugeriu a "dispersão geral da aldeação" dos indígenas, suspendendo o Diretório e sujeitando-os "à política como os demais cidadãos":

Fazemos mais lembrar não ser hoje dificultosa a separação dos índios aldeados, porque grassando a terribilíssima seca do ano próximo passado 1825, a peste, o recrutamento, absorveram quase toda essa desgraçada gente, digna por certo de melhor sorte. Aos índios, somos de parecer, se lhes concederão com justiça e equidade os antigos direitos de suas propriedades, datas e sesmarias de terras para a sua cultura, não pagando rendimento delas, e mesmo preferindo aos mais concidadãos. Quando pois se mande que os índios se dispersem de suas aldeias e vivam onde muito quiserem, parece-nos que estas datas devem passar ao domínio direto das câmaras respectivas para aforá-las a quem quiser ser útil à província pela sua cultura, não ficando deste modo incultas como tem sucedido no poder dos índios, que nem cultivam todas e nem deixavam os extranaturais cultivar, sem precedência de choques e contestações. No caso, porém, de não parecer conveniente a dispersão de poucos índios que hoje existem na província, [...] os índios de Monte-mor Novo, Monte-mor Velho, e os de Messejana e Arronches deverão ser aldeados na vila de Soure [...]. Quando aconteça serem abolidas 
ou suprimidas as vilas de Messejana e Arronches, neste caso as terras que se deram aos índios que delas se desaldearem deverão ser incorporadas nos próprios reais. ${ }^{\mathbf{2 8}}$

No mês de novembro, o presidente da província, Antônio de Sales Nunes Berford, apresentou suas considerações. Argumentou que "pelo desastroso e completo transtorno que tem causado a fome e a peste de 1824 para cá", a civilização dos indígenas se achava "de todo corrompida e com a relaxação ou quase aniquilação em que nestes últimos tempos têm ficado esses mesmos diretórios". Por conta do "estado de redução em que se acham os índios desta província por efeito das mencionadas secas e peste", Berford sugeriu que se mantivesse apenas a "vila de Soure, povoação de Almofala e Vila Viçosa", extinguindo todas as outras, inclusive Messejana. "Se os índios desta província, poucos como são atualmente, se reunirem em os aldeamentos mencionados, [...] decerto eles poderão ser muito úteis [...] em diminuir-se nesta província a necessidade da população escrava", completou. ${ }^{29}$

Maico Xavier observou que "o discurso de que a população indígena decrescia vinha sendo fortemente propagado desde o século XVIII", mas se fortaleceu com a formação do Estado nacional e em decorrência dos efeitos da seca. $O$ autor também atentou para a contradição do governo de enfatizar a diminuição numérica dos índios e, ao mesmo tempo, elencá-los como alternativas à mão de obra escrava (2015, p. 106). A demografia indígena foi fortemente impactada com a seca e as consequentes mortes e dispersões, mas a intenção das autoridades ao concentrá-los em poucos lugares visava organizar a disponibilidade de força de trabalho livre e liberar as terras que Ihes pertenciam sob a administração de suas câmaras (XAVIER, 2015, p. 108-110).

Acerca da problemática indígena no Ceará do século XIX, Carlos Guilherme do Valle defende que "tratar da terra implicava também lidar com o uso da mão de obra disponível" (2009, p. 31), o que também abrangia as "populações ditas pobres" e "tidas como desclassificadas de uma forma geral", como indica Reginaldo Araújo (2018, p. 172). Por isso, essa conjuntura marcou a investida mais violenta do poder provincial do Ceará contra os direitos dos índios, em cujo projeto a usurpação das terras, o controle da mão de obra, a supressão de vilas e câmaras e a desarticulação dos espaços de atuação política indígena estavam intimamente interligados.

O Plano Geral de Civilização dos Índios nunca aconteceu, mas as ideias do Conselho passaram gradativamente a se concretizar no Ceará. As transformações administrativas levadas a cabo pelo legislativo nacional tendiam a concentrar cada vez mais poder nos governos provinciais, superando a perspectiva corporativa do Antigo Regime em prol do ideário individualista liberal (SLEMIAN, 2009, p. 47-142; SOUZA, 2016, p. 258-259). No caso cearense, por exemplo, as famílias até então posicionadas nos poderes municipais, passaram a ocupar os cargos governativos da província ou do legislativo imperial (ARAÚJO, 2018, p. 136-140). Nesse mesmo contexto, as comunidades indígenas enquanto corpo social perderam força diante da atuação das elites político-econômicas provinciais, ambiciosas das terras dos índios. Prova disso é que os "socorros públicos" como dever do Estado tinham um peso muito maior 
após a seca de 1825 do que as relações de vassalagem (OLIVEIRA, 2019, p. 168), que não foram suficientes para que os índios mantivessem seus direitos políticos como mercês do rei. Com as propostas de desaldeá-los e de abolir o Diretório, acabaram os cargos indígenas de câmara municipal e desembaraçaram as resistências políticas que os índios impunham por meio dos senados. A lei pombalina não foi abolida pela importância que tinha a mão de obra indígena, e ainda que seus direitos fundiários continuassem previstos, a garantia de respeito a eles se fragilizou bastante sob a administração de gestores não-indígenas. Ou seja, mesmo que não questionassem a prerrogativa de posse da terra dos índios, foram criadas condições jurídicas e administrativas para que delas se desgarrassem ou fossem expulsos. A seca de 1825 , com efeitos exagerados ou não, impulsionou as articulações anti-indigenistas que se concretizaram nos anos seguintes (XAVIER, 2015, p. 119-128).

Em dezembro de 1825 e abril de 1826, antes do parecer emitido pelo Conselho Provincial, vereadores da vila de brancos de Aquiraz produziram requerimentos ao rei para que os indígenas da povoação de Monte-mor Velho fossem transferidos para alguma vila de índios próxima a Fortaleza, por praticarem roubos e pelo fato de a povoação estar quase desabitada. Autorizada em agosto, a remoção ocorreu em janeiro de 1827 para Messejana. ${ }^{30}$ No ano seguinte, os repúblicos de Monte-mor Novo seguiram o exemplo de Aquiraz, com o agravante de que aquela era vila de índios. Por meio do relato mencionado há pouco, argumentaram que os poucos indígenas sobreviventes à seca deveriam ser transferidos para outro lugar mais propício, liberando, assim, suas terras para o cultivo dos extranaturais. ${ }^{31}$ A remoção aconteceu também para Messejana entre 1830 e $1831 .^{32}$

Messejana também passou pelo mesmo impacto demográfico nesse período. Em julho de 1826, o governo da província exigiu o reenvio de um mapa da população da vila em que não havia constado os índios, ${ }^{33}$ o que sugere uma tentativa de apagamento nos registros municipais. Em setembro, o Conselho Geral da Província decidiu suprimir as "cadeiras de primeiras letras de Messejana, Arronches e Soure, atenta a nenhuma atual utilidade das mesmas". ${ }^{34}$ Em 15 de outubro de 1827, foi promulgada uma lei que mandava criar escolas nas cidades e vilas mais populosas do império, ${ }^{35}$ o que sobrepujava o Diretório ainda em vigor no Ceará, que exigia a educação para as crianças indígenas independentemente do tamanho da povoação. No ano seguinte, o Conselho Geral do Ceará decidiu que as duas vilas de índios de Soure e Arronches não teriam mais escolas porque "se acha[vam] quase aniquiladas, e [por] haver-se proposto a supressão das mesmas, reunindo-se seus habitantes aos da vila de Messejana", ${ }^{36}$ contemplada talvez por ter recebido os índios de Monte-mor Velho, e com expectativa de receber os das outras duas povoações mencionadas. As ações praticadas pelas autoridades cearenses nesses anos implodiam garantias indígenas, descumpriam o Diretório ainda em vigor e indicavam a degradação das vilas de índios. Por exemplo, a população indígena de Messejana se encontrava dispersa ainda em 1828 "pelas secas ultimamente sofridas". ${ }^{37}$

Também em 1828 foi promulgada a lei de $1^{\circ}$ de outubro, que regulamentou o novo formato das câmaras municipais. Ela foi fatal para os povos indígenas das 
vilas pombalinas e surgiu em um contexto avançado de usurpação do patrimônio das comunidades. A documentação produzida no senado de Messejana em 1829 é indício de que a instituição já não era mais ocupada por índios. A pesquisa ainda não conseguiu identificar todos os que assinavam as comunicações produzidas a partir desse ano, a não ser a de João da Cunha Pereira, diretor da vila. Em 12 de junho, pediram providências ao presidente da província acerca das terras do termo da vila, que haviam sido cedidas a donos de lotes vizinhos pelos índios, por serem estes "homens de pouco senso". Na mesma comunicação, o diretor Pereira expôs que as terras do Alagadiço estavam "quase todas ocupadas pelos moradores brancos", e sugeriu se escolhesse algumas áreas para que os indígenas ficassem nos anos secos. ${ }^{38}$

No dia seguinte, outro ofício foi dirigido pelos vereadores de Messejana ao presidente da província com maiores explicações sobre a situação das terras, "dadas aos índios por ordem de sua majestade fidelíssima antes muito da criação desta vila", e que deveriam ser conservadas "na mesma posse como patrimônio de seus ascendentes". Segundo eles, "alguns indivíduos que possuem terras mestiças" se introduziram nelas, mais precisamente nos lugares Guaiúba e Jabuti, processo só interrompido pelo ex-governador Sampaio que "mand[ara] restituir tudo ao antigo estado [...], como determinava as posses antigas” - o que explicava a gratidão da antiga formação da câmara em 1820. Porém, após o término do seu mandato, acabara-se

a boa ordem que então reinava, renovando suas malícias, aterrando os miseráveis índios, requerendo conversão com suborno perante o ex-ouvidor Leal com concessão do exdiretor Florêncio, determinando aos índios que fossem à vila do Aquiraz por ordem do dito ouvidor e lá se convencionou como foi do agrado dos intrusos possuidores, e porque os índios são homens naturalmente estúpidos, sem que ali estivesse o seu diretor, estiveram e assinaram tudo quanto se lhe ofereceu, que desgraça!!!39

A forma depreciativa com que se referiam aos índios infere que a câmara de Messejana já não era mais ocupada por eles. Os então vereadores não levavam em consideração as possíveis dificuldades pelas quais os indígenas passavam e o que Ihes era oferecido em contrapartida pelos proprietários vizinhos. O tom de denúncia com que se referiam aos antigos ouvidor, diretor e aos usurpadores das terras, e o lamento pelo que os índios perderam provavelmente não eram uma demonstração de altruísmo dos repúblicos. Mais plausível é a compreensão de que defendiam as terras indígenas porque compunham o termo da vila, de cuja produção dependia os rendimentos da câmara, que talvez quisessem se apossar individualmente, e que já vinham sendo retalhadas havia muitos anos. No entanto, como vimos anteriormente, esse processo era motivo de antigas reclamações pelos indígenas, o que contradizia com a alegada "estupidez".

A lei de 1828 também implicava, em tese, que o Diretório ainda vigente em algumas regiões deveria ser abolido. No entanto, no Ceará, produziu-se uma situação de confusão jurídica. Apesar da diminuição demográfica nas vilas e povoações de 
índios a partir de 1825, do parecer do Conselho Provincial de 1826 e da espoliação política e fundiária já iniciada em Monte-mor Velho e Monte-mor Novo, as populações restantes nos lugarejos pombalinos permaneciam subordinadas ao diretor e com direito às terras previstas no Diretório. Já o acesso aos cargos nas câmaras ficou sujeito à nova legislação do império. Como afirma Reginaldo Araújo, "a formação do Estado-Nação na província do Ceará representou para os pobres livres, de imediato, um desastre", que não se resumia aos recrutamentos, conflitos armados e "violência institucionalizada" trabalhados pelo autor (ARAÚJO, 2018, p. 205-206). Por exemplo, os índios foram rapidamente espoliados dos antigos direitos políticos, permanecendo apenas sua condição de mão de obra.

A proposta de posturas enviada pela câmara de Messejana, em junho de 1829, é prova dessa situação. Foi rejeitada pelo Conselho e governo da província do Ceará em julho porque os artigos 4 e 6 - que previam, respectivamente, a liberação do "contrato de aguardente para aumento de suas rendas" e a taxação das casas de extranaturais - iam contra o "Diretório ainda em vigor", e também porque o artigo 5 infringia a "lei regimental das câmaras de $1^{\circ}$ de outubro de 1828". ${ }^{40}$ Buscava-se a anulação pontual de determinados artigos do Diretório para que se mantivesse a garantia do trabalho indígena. Mesmo se beneficiando com a nova legislação, as elites políticas de Messejana buscavam alternativas para incrementar as rendas do senado e não correr o risco de ver a vila extinta. A ameaça era eminente porque, em agosto de 1829, ainda havia relatos de que "muitos índios da direção de Messejana [...] tem se dispersado da mesma a fim de ficarem por essa forma livres das vistas do seu respectivo diretor". ${ }^{41}$

A dispersão dos índios como fuga dos diretores era um fenômeno antigo nas povoações indígenas sob o Diretório, bastante presente em relatos da época e muito abordada pela historiografia. Desde o início do século XIX, uma quantidade significativa de índios conseguia se estabelecer em termos de vilas de brancos, se alistar nas ordenanças e ser registrada como brancos em mapeamentos populacionais por adquirir um terreno produtivo (MAIA; COSTA, 2018). Mas o que ocorreu a partir de 1825 pode ser entendido como uma diáspora, fragilizando inclusive as garantias fundiárias das comunidades, mesmo que a fuga se desse para lugares dentro do termo da vila - no caso de Messejana, como as já citadas Guaiúba e Jaboti, e, ainda assim, impondo dificuldades ao controle do diretor e esvaziando o núcleo urbano da sede municipal. Em 1829, após a abolição dos direitos políticos das lideranças, os índios se viam ainda mais compelidos a escapar do trabalho forçado (XAVIER, 2015, p. 112-115). Em contrapartida, era desejo de muitos que a dispersão indígena se concretizasse.

Com o crescente esvaziamento dos povoados indígenas, as propostas de abolição ganharam corpo. Em dezembro de 1829, o Conselho de Governo do Ceará propôs que fossem "suprimidas as vilas de índios de Messejana, Arronches e Soure, ficando estas sujeitas à administração desta cidade [Fortaleza]" por "existirem bem poucos índios". ${ }^{42}$ Em janeiro do ano seguinte a supressão foi novamente proposta, 
que sofrem dos diretores que abusivamente são os que mais se utilizam de seus braços, para aumento de suas lavouras, vivendo pelo Diretório sujeitos ao capricho dos ditos diretores, quando aliás devem ser considerados como qualquer outro cidadão. ${ }^{43}$

O aparente altruísmo dos conselheiros perante a situação dos índios era, na verdade, expressão das ambições das elites de Fortaleza e Aquiraz de se apossarem dos termos das vilas de índios, convenientemente pouco habitadas. Como argumento para abolir definitivamente o Diretório, dispersar os índios e se apoderar dos patrimônios das câmaras e das terras indígenas, valeram-se até mesmo de enquadrá-los como cidadãos, mesmo sem considerá-los capazes de ocupar os "cargos de governança" (COSTA, 2018, p. 97-98). Ou seja, não se trata apenas da pouca abrangência do "discurso cidadão" das autoridades provinciais em relação às populações pobres não-escravas, como discute Reginaldo Araújo (2018, p. 176), mas como esse mesmo discurso foi utilizado para a exclusão política e desmantelamento dos direitos dos índios. Por outro lado, na perspectiva indígena, a cidadania tinha significado bem diferente por qualificá-los a uma vida autônoma e um autogoverno amplo, sem diretores e com direitos políticos, como vimos no memorial de sete anos antes.

O Diretório seguiu vigente no Ceará em 1830, pelo menos no que dizia respeito à organização do trabalho indígena, como revela a renovação do cargo de João da Cunha Pereira como diretor dos índios de Messejana em fevereiro. ${ }^{44}$ Enquanto isso, os vereadores da vila buscavam garantir a existência do município, também demonstrando suposta preocupação com os índios, mas por motivo diferente do Conselho da Província. Em ofício ao vice-presidente do Ceará de agosto de 1830, relataram que a câmara detinha as

serras e logradouros de que os mesmos índios se achavam de posse, como se vê do termo de sua criação, porém, a vila do Aquiraz nos tem roubado parte do termo e freguesia porque alguns indivíduos que têm terras mestiças com as dos índios se têm apossado de parte delas, bem como da povoação da Guaiúba, que sendo terras dos índios (ela tinha logradouros) e Cararapió, que sempre foi e é dos índios, e o Aquiraz quer que seja freguesia e termo seu, trazendo para aresto que Tamatanduba é extrema, quando até da parte de lá da dita Tamatanduba tem marcos de serra do quadro, e assim, Ex. Sr., visto o que se vai praticando, ficarão os índios sem suas terras, e a câmara sem seus limites, e o vigário sem freguesia, de V. Ex. esperamos o bom êxito de nossa requisição. ${ }^{45}$

Mesmo sem ainda conhecermos a origem de todos os que assinam a carta, é possível afirmar que o documento acima é mais um indício de que os índios já haviam sido expropriados de tudo o que o Diretório ainda em vigor Ihes garantia. Ausentes do senado da vila, não estavam de posse nem da própria terra que a câmara assumia ser deles, o que indicava uma situação jurídica e fundiária francamente contraditória e o agravamento da dispersão. Mas o interesse da administração municipal na preservação 
do patrimônio indígena, assim como o do Conselho Provincial, não era propriamente cuidar dos direitos indígenas, mas, sim, de salvar a própria existência. Quanto mais Fortaleza e Aquiraz abocanhavam pedaços de terras indígenas, dificultava-se a arrecadação pela câmara de Messejana e mais se aproximava sua extinção. Já os índios da vila, cujas lideranças haviam sonhado com uma vida mais autônoma no advento do liberalismo, se viam sem as serras, logradouros, povoações e direitos políticos que eram e sempre foram seus. Passaram a protagonizar uma situação diaspórica semelhante ao que Vânia Moreira observou no Espírito Santo de cerca de 30 anos antes, com a promulgação da Carta Régia de 1798, que abolira o Diretório. Por lá, os índios sofreram com um processo de subalternização decorrente da "progressiva exclusão deles do governo local” (MOREIRA, 2019, p. 306) e as vilas também se esvaziaram (MOREIRA, 2019, p. 348). Para a autora,

\begin{abstract}
a diáspora distanciava os índios de suas terras coletivas, que eram, àquela altura, um dos elementos diacríticos que reforçavam seu status jurídico, político e social de índios aldeados e/ou vilados. Ao deixarem suas terras e repúblicas, lançavam-se em uma situação social e jurídica inédita e isso certamente exigiu deles novas estratégias políticas e identidades sociais para lidar com uma sociedade escravista e inclinada a impor aos pobres livres, geralmente considerados mestiços, diferentes modalidades de opressão social (MOREIRA, 2019, p. 341).
\end{abstract}

De forma semelhante, para os índios que sobreviveram à seca de 1825, no Ceará, só restava a fuga do trabalho forçado.

\title{
Considerações finais
}

Com idas e vindas no legislativo cearense, a vila (não mais de índios) de Messejana foi extinta por meio da lei no 188 de 22 de dezembro de 1839, com seu termo dividido entre Fortaleza e Aquiraz.46 A essa altura, os direitos dos índios já haviam sido brutalmente atropelados pelo processo de fortalecimento das elites provinciais encetado nos primeiros anos do Brasil independente. O esfacelamento do território de algumas das antigas vilas pombalinas era apenas uma etapa cruel da já avançada usurpação de prerrogativas indígenas, havia muito inadmissíveis aos olhos dos colonos. Com a promulgação da lei das câmaras de 1828 e o fim do Diretório no Ceará provavelmente em 1831, Monte-mor Novo e Viçosa - antes, vilas de índios conseguiram permanecer existindo por estarem distantes da capital. Soure, Arronches e Messejana, que formavam um cinturão indígena ao redor de Fortaleza, foram retalhadas pela ambição das elites fortalezenses que passaram a ganhar espaço no poder provincial. Nesse momento, os índios já haviam sido enxotados das câmaras, perderam suas posições militares com o fim das ordenanças em 1831 e ficaram apenas com um teórico direito à terra, garantia bastante fragilizada pelo enfraquecimento de suas lideranças e desagregação das comunidades.

No entanto, no advento do liberalismo, as expectativas indígenas eram bem diferentes. Desde, pelo menos, a promulgação do Diretório, a luta dos índios era não 
apenas pela manutenção de seus territórios, mas, principalmente, em prol da ampliação do horizonte aberto com a declaração da liberdade e igualdade enquanto súditos, privilégios provenientes da monarquia com quem mantinham antigas e estreitas relações. No entanto, os ventos liberais e constitucionais sopravam em direções diferentes, a depender de quem fosse atingido por eles, como vimos com a história dos índios de Messejana, na década de 1820. Por um lado, o memorial de 1822 e outras fontes escritas indígenas das câmaras municipais revelam importantes aspectos da sua cultura política e que viram nesse momento a esperança de concretizar o sonho de viver com igualdade e autonomia plenas. Além disso, os documentos escancaravam a falácia das acusações de inaptidão política dos índios e as limitações do projeto de criação de um campesinato indígena produtivo, de vilas rentáveis e de câmaras viáveis enquanto a população continuasse a ser explorada como mão de obra forçada e a ser enquadrada como incapaz.

Por outro lado, as elites político-econômicas provinciais interpretaram o liberalismo como a oportunidade de fortalecimento de seus poderes locais sem quaisquer tipos de limitações. O constitucionalismo possibilitou a instrumentalização cruel do conceito do "ser cidadão": se, para os índios, ser cidadão significava o aprimoramento da igualdade, para os poderosos a cidadania indígena era um argumento eficaz para abolir privilégios especiais. Com isso, desde o legislativo nacional, com a Constituição de 1824, até ao que se decidiu provincialmente, os direitos indígenas foram pilhados em uma velocidade impressionante após a independência. Para os índios das antigas povoações pombalinas, a formação do Estado nacional brasileiro significou sua exclusão dos espaços políticos institucionais e a criação de uma sociedade de cidadãos despossuídos. Antes vereadores das próprias câmaras municipais, restou-lhes apenas uma cidadania precária.

\section{Referências}

ALMEIDA, Maria Regina Celestino de. Comunidades indígenas e Estado nacional: histórias, memórias e identidades em construção (Rio de Janeiro e México - séculos XVIII e XIX). In: ABREU, Marta; SOIHET, Rachel; GONTIJO, Rebeca (Org.). Cultura política e leituras do passado: historiografia e ensino de história. Rio de Janeiro: Civilização Brasileira, 2007.

ARAÚJO, José de Souza Azevedo Pizarro e. Memória histórica do Rio de Janeiro e das províncias anexas à jurisdição do vice-rei do Estado do Brasil, dedicadas a El rei o Senhor dom João VI. Rio de Janeiro: Tipografia de Silva Porto, 1822, tomo VIII.

ARAÚJO, Reginaldo Alves de. A parte no partido: relações de poder e política na formação do Estado brasileiro, na província do Ceará (1821-1841). Tese (Doutorado em História) - Universidade Federal do Ceará, 2018.

BICALHO, Maria Fernanda. As câmaras municipais no império português: o exemplo do Rio de Janeiro. Revista Brasileira de História, vol. 18, n. 36, 1998. 
CARVALHO, Antônio Rodrigues de. Memória sobre a capitania do Ceará no ano de 1816. Publicações do Arquivo Nacional. Rio de Janeiro: Oficina Gráfica do Arquivo Nacional, n. XXIV, 1929.

COSTA, João Paulo Peixoto. Na lei e na guerra: políticas indígenas e indigenistas no Ceará (1798-1845). Teresina: EDUFPI, 2018.

COSTA, João Paulo Peixoto. Atuação política indígena na câmara municipal da vila de índios de Monte-mor Novo no Ceará. Faces da História, vol. 7, n 1, p. 97-115, 2020 a.

COSTA, João Paulo Peixoto. Cultura política indígena na câmara municipal da vila de índios de Messejana no Ceará. Cadernos de Pesquisa do CDHIS, vol. 32, n. 2, p. 34-54, 2019.

COSTA, João Paulo Peixoto. Disciplina e invenção: civilização e cotidiano indígena no Ceará (1812-1820). Teresina: EDUFPI, 2015.

COSTA, João Paulo Peixoto. Dolorosa lembrança: o fim do estatuto de vila de índios em Monte-mor Novo (Ceará, 1828-1831). Revista Escripturas, vol. 4, n 1, 2020 b.

DANTAS, Mariana Albuquerque. Dimensões da participação política indígena: Estado nacional e revoltas em Pernambuco e Alagoas, 1817-1848. Rio de Janeiro: Arquivo Nacional, 2018.

FRAGOSO, João. GOUVÊA, Maria de Fátima Silva. BICALHO, Maria Fernanda. Uma leitura do Brasil colonial: bases da materialidade e governabilidade do império. Penélope, n. 23, 2000.

GÓMEZ, Julio Sánchez. Invisibles y olvidados: indios e independencia de Brasil. Studia Historica. Historia Contemporánea, n. 27, 2009, p. 235-277.

GOUVÊA, Maria de Fátima Silva. Poder, autoridade e o senado da câmara do Rio de Janeiro, ca. 1780-1820. Revista Tempo, n. 13, 2002, p. 111-155.

KOSTER, Henry. Viagens ao nordeste do Brasil. Rio de Janeiro/São Paulo/Fortaleza: ABC Editora, 2003.

LOPES, Fátima Martins. Em nome da liberdade: as vilas de índio do Rio Grande do Norte sob o Diretório pombalino no século XVIII. Tese (Doutorado) - Universidade Federal de Pernambuco, 2005.

LOPES, Fátima Martins. Oficiais de ordenanças de índios: novos interlocutores nas vilas da capitania do Rio Grande do Norte. Anais do XXV Simpósio Nacional de História - ANPUH. Fortaleza, 2009.

MAIA, Lígio José de Oliveira. Serras de Ibiapaba. De aldeia a vila de índios: vassalagem e identidade no Ceará colonial - século XVIII. Tese (Doutorado em História), Universidade Federal Fluminense, 2010.

MAIA, Lígio José de Oliveira. COSTA, João Paulo Peixoto. Antônio de Verçosa, alferes ou vaqueiro? Disciplina e invenção indígena no Ceará oitocentista. Os Brasis e suas Memórias: Memórias Indígena. Rio de Janeiro: CAPES/LACED/PPGAS-UFRJ/Museu 
Nacional, 2018. Disponível em: https://osbrasisesuasmemorias.com.br/biografiaantonio-de-vercosa/. Acesso em: 13 ago 2020.

MONTEIRO, John Manuel. Tupis, tapuias e historiadores: estudos de história indígena e do indigenismo. Tese (Concurso de Livre-docência), 2001.

MOREIRA, Vânia Maria Losada. Autogoverno e economia moral dos índios: liberdade, territorialidade e trabalho (Espírito Santo, 1798-1845). Revista de História, n 166, 2012, p. 223-243.

MOREIRA, Vânia Maria Losada. Reinventando a autonomia: liberdade, propriedade, autogoverno e novas identidades indígenas na capitania o Espírito Santo, 1535-1822. São Paulo: Humanitas, 2019.

NOGUEIRA, Gabriel Parente. Viver à lei da nobreza: elites locais e o processo de nobilitação na capitania do Ceará Grande (1748-1804). Curitiba: Appris, 2017.

NEVES, Lúcia Maria Bastos Pereira das. Corcundas e constitucionais: a cultura política da independência (1820-1822). Rio de Janeiro: Revan/FAPERJ, 2003.

OLIVEIRA, Gabriel Pereira de. "Eu não dei meu dinheiro para inglês nenhum": o ideal de nação e a seca de 1825 no norte do Brasil. Revista de História Regional, vol. 24, n. 1, p. 160-178, 2019.

SANTOS, Raquel Dani Sobral. A construção do estatuto de cidadão para os índios do Grão-Pará (1808-1822). Dissertação (mestrado) - Universidade de São Paulo, 2013.

SILVA, Isabelle Braz Peixoto da. Vilas de índios no Ceará Grande: dinâmicas locais sob o Diretório Pombalino. Campinas: Pontes Editora, 2005.

SLEMIAN, Andréa. Sob o império das leis: Constituição e unidade nacional na formação do Brasil (1822-1834). São Paulo: Hucitec/FAPESP, 2009.

SOUZA, lara Lis Franco Schiavinatto Carvalho. Pátria coroada: o Brasil como corpo político autônomo: 1780-1831. São Paulo: Fundação Editora da UNESP, 1999.

SOUZA, Williams Andrade de. A administração local no Brasil imperial: notas preliminares sobre as municipalidades nos debates parlamentares. Clio: Revista de Pesquisa Histórica, vol. 34, n 1, 2016.

VALLE, Carlos Guilherme do. Conflitos, identidades e aldeamentos indígenas no Ceará do século XIX: um exercício de antropologia histórica. In: VALLE, Carlos Guilherme do. SCHWADE, Elisete. Processos sociais, cultura e identidades. São Paulo: Annablume, 2009.

XAVIER, Maico Oliveira. "Cabôcullos são os brancos": dinâmicas das relações sócioculturais dos índios do termo da Vila Viçosa Real - século XIX. Dissertação (Mestrado) - Universidade Federal do Ceará, 2010.

XAVIER, Maico Oliveira. Extintos no discurso oficial, vivos no cenário social: os índios do Ceará no período do império do Brasil - trabalho, terras e identidades indígenas em questão. Tese (doutorado) - Universidade Federal do Ceará, 2015. 


\section{Notas}

${ }^{1}$ BRASIL. Lei de $1^{\circ}$ de outubro de 1828. Dá nova forma às câmaras municipais, marca suas atribuições e o processo para sua eleição, e dos juízes de paz. Disponível em: http://planalto. gov.br/ccivil_03/Leis/LIM/LIM-1-10-1828.htm. Acesso em: 11 de agosto de 2020. Título II, art. 24.

20 Diretório ainda criou as povoações de índios de Baepina (no termo de Viçosa, atual Ibiapina, na serra de Ibiapaba), Almofala (no termo de Sobral, atual terra indígena da etnia Tremembé, no município de Itarema) e Monte-mor Velho (no termo de Aquiraz, atual Pacajus, na região metropolitana de Fortaleza).

3 Ibid. Título I, art. 3 e 4 e título V, art. 90.

4 "serão obrigados a conservar com os índios aquela recíproca paz, e concórdia, que pedem as Leis da humana Civilidade, considerando a igualdade, que tem com eles na razão genérica de Vassalos de Sua Majestade, e tratando-se mutuamente uns a outros com todas aquelas honras, que cada um merecer pela qualidade das suas Pessoas, e graduação de seus postos". DIRETÓRIO que se deve observar nas povoações dos índios do Pará, e Maranhão, enquanto sua Majestade não mandar o contrário. Lisboa: Oficina de Miguel Rodrigues, 1758, §83.

5 Termo presente na documentação referente aos membros do senado da câmara.

6 ARQUIVO NACIONAL. Da câmara de Messejana ao rei dom João VI. Messejana, 3 de janeiro de 1820, Câmara de Messejana (8J), p. 106V-107V.

7 BIBLIOTECA NACIONAL. Ofício da câmara de Messejana ao Governo Provisório. Messejana, 15 de janeiro de 1822, códice II-32, 24, 9.

8 Por isso, e em meio à onda de antilusitanismo, seria vítima de uma rebelião de índios do povoado em setembro deste mesmo ano (COSTA, 2018, p. 147-154).

9 Francisco Pereira Correia Lima foi um dos assinantes do requerimento de Messejana de 1816 analisado anteriormente (COSTA, 2018, p. 274). Antônio Francisco Pereira foi nomeado capitãomor indígena de Messejana em junho de 1818 (COSTA, 2018, p. 259).

10 BIBLIOTECA NACIONAL. Memorial que foi assinado da câmara desta vila de Messejana com assistência dos repúblicos e mais povo. Anexo ao ofício da câmara de Messejana ao Governo Provisório. Messejana, 15 de janeiro de 1822, códice II-32, 24, 9.

11 BIBLIOTECA NACIONAL. Memorial..., códice II-32, 24, 9.

12 ARQUIVO NACIONAL. Vereação da câmara de Messejana, 27 de agosto de 1812. Anexo ao ofício de Manuel Ignácio de Sampaio ao conde de Aguiar. Fortaleza, 1 de abril de 1814, série Interior - Negócios de Províncias (AA), códice IJJ9 168.

13 BIBLIOTECA NACIONAL. Memorial..., códice II-32, 24, 9.

14 BIBLIOTECA NACIONAL. Memorial..., códice II-32, 24, 9.

15 ARQUIVO HISTÓRICO ULTRAMARINO. De Manoel de Magalhães Pinto e Avelar à rainha dona Maria I. Aquiraz, 1786, Conselho Ultramarino, série Ceará, caixa 11, documento 638.

16 BIBLIOTECA NACIONAL. De José Rabelo de Souza Pereira a Manuel Ignácio de Sampaio. Fortaleza, 11 de julho de 1815, códice C-199, 14.

17 BIBLIOTECA NACIONAL. Memorial..., códice II-32, 24, 9.

18 BIBLIOTECA NACIONAL. Memorial..., códice II-32, 24, 9. 
19 ARQUIVO PÚBLICO DO ESTADO DO CEARÁ. Abaixo-assinado dos índios da Ibiapaba à rainha dona Maria I, anexo ao ofício do Marquês de Aguiar a Manuel Ignácio de Sampaio. Rio de Janeiro, 20 de outubro de 1814, fundo Governo da Capitania (GC), livro 93.

20 ARQUIVO PÚBLICO DO ESTADO DO CEARÁ. De Francisco Alberto Rubim à câmara de Messejana. Fortaleza, 20 de dezembro de 1820, GC, livro 101, p. 137V.

21 BIBLIOTECA NACIONAL. Memorial..., códice II-32, 24, 9.

22 ARQUIVO PÚBLICO DO ESTADO DO CEARÁ. De Francisco Alberto Rubim a Atanásio Faria Maciel. Fortaleza, 18 de janeiro de 1821, GC, livro 101, p. 168V.

${ }^{23}$ ARQUIVO PÚBLICO DO ESTADO DO CEARÁ. Registro da provisão de professor de primeiras letras da vila de Messejana passada a João da Costa Pontes. Fortaleza, 12 de julho de 1822, GC, livro 84, p. 53.

24 ARQUIVO NACIONAL. De Tristão Gonçalves de Alencar Araripe à câmara de Arronches. Fortaleza, 21 de julho de 1824. Diário do Governo do Ceará. Fortaleza, 30 de julho de 1824, n. 15, p. 1V, série Confederação do Equador (IN), caixa 742, pacote 4.

25 PROPOSTA de Francisco Gomes Parente. Fortaleza, 17 de dezembro de 1829. ATAS do Conselho Geral da Província do Ceará: 1829-1835. Fortaleza: INESP, 1997, p. 159-160.

26 BIBLIOTECA NACIONAL. Abaixo-assinado da câmara e povos da vila de Monte-mor Novo, 7 de janeiro de 1828. Anexo ao ofício de José Lino Coutinho, Rio de Janeiro, 20 de agosto de 1831, códice II-32, 24, 15.

27 BIBLIOTECA NACIONAL. Memória estatística para a província do Ceará, códice II-32, 23, 61.

28 PARECER do Conselho de Governo da Província do Ceará, 22 de setembro de 1826. In: Documentos sobre os nossos indígenas. Revista do Instituto do Ceará. Fortaleza: Editora "Instituto do Ceará", tomo LXXVII, 1963, p. 323-324.

29 De Antônio de Sales Nunes Barford a José Feliciano Francisco Ribeiro. Fortaleza, 3 de novembro de 1826. In: NAUD, Leda Maria Cardoso. Documentos sobre o índio brasileiro (1500-1822): $2^{a}$ parte. Revista de Informação Legis/ativa, vol. 8, n. 29, 1971, p. 306.

30 BIBLIOTECA NACIONAL. Da câmara de Aquiraz a dom Pedro I. Aquiraz, 12 de dezembro de 1825, códice II-32, 23, 83, n¹. BIBLIOTECA NACIONAL. Da câmara de Aquiraz a dom Pedro I. Aquiraz, 24 de abril de 1826, códice II-32, 23, 83, n¹. ARQUIVO PÚBLICO DO ESTADO DO CEARÁ. De José Feliciano Fernandes Pinheiro a Antônio de Sales Nunes Berford. Rio de Janeiro, 18 de agosto de 1826, fundo Ministérios (MN), Ministério do Império (MI), livro 89. ARQUIVO PÚBLICO DO ESTADO DO CEARÁ. De Antônio de Sales Nunes Berford a João da Cunha Pereira. Fortaleza, 18 de janeiro de 1827, fundo Governo da Província (GP), série Correspondências Expedidas (CO EX), livro 4, p. 178V-179.

31 BIBLIOTECA NACIONAL. Abaixo-assinado da câmara e povos da vila de Monte-mor Novo, 7 de janeiro de 1828. Anexo ao ofício de José Lino Coutinho, Rio de Janeiro, 20 de agosto de 1831, códice II-32, 24, 15.

32 ARQUIVO NACIONAL. Ofício de José Lino Coutinho ao vice-presidente do Ceará. Rio de Janeiro, 20 de agosto de 1831, AA, códice IJJ9 56.

33 ARQUIVO PÚBLICO DO ESTADO DO CEARÁ. De José de Castro e Silva a João da Cunha Pereira. Fortaleza, 6 de julho de 1826, GP, CO EX, livro 7, p. 24. 
34 ARQUIVO PÚBLICO DO ESTADO DO CEARÁ. De Antônio de Sales Nunes Berford a José Alexandre de Amorim Garcia. Fortaleza, 15 de setembro de 1826, GP, CO EX, livro 4, p. 128-128V.

35 Lei de 15 de outubro de 1827. Manda criar escolas de primeiras letras em todas as cidades, vilas e lugares mais populosos do império. Disponível em: https://www2.camara.leg.br/legin/fed/ lei_sn/1824-1899/lei-38398-15-outubro-1827-566692-publicacaooriginal-90222-pl.html. Acesso em 13 de agosto de 2020.

${ }^{36}$ ARQUIVO NACIONAL. Sessão do Conselho Geral da Província do Ceará de 25 de junho de 1828, anexo ao ofício de Antônio de Sales Nunes Berford a Pedro de Araújo Lima. Fortaleza, 28 de junho de 1828, AA, códice IJJ9 171.

37 ARQUIVO PÚBLICO DO ESTADO DO CEARÁ. De Antônio de Sales Nunes Berferd a João da Cunha Pereira. Fortaleza, 24 de julho de 1828, GP, CO EX, livro 10, p. 93V-94.

38 ARQUIVO PÚBLICO DO ESTADO DO CEARÁ. Da câmara municipal de Messejana ao presidente da província do Ceará. Messejana, 12 de junho de 1829, fundo Câmara Municipais (CM), Messejana (MS), pacotilha 1829-1832.

39 ARQUIVO PÚBLICO DO ESTADO DO CEARÁ. Ofício da câmara de Messejana ao presidente da província do Ceará. Messejana, 13 de junho de 1829, CM, MS, pacotilha 1829-1832.

40 ARQUIVO PÚBLICO DO ESTADO DO CEARÁ. De Joaquim Pereira da Silva e Francisco Esteves de Almeida à câmara de Messejana. Fortaleza, 6 de julho de 1829, GP, CO EX, livro 13, p. 70.

${ }^{41}$ ARQUIVO PÚBLICO DO ESTADO DO CEARÁ. De Manuel Joaquim Pereira da Silva a Joaquim da Cunha Pereira. Fortaleza, 5 de agosto de 1829, GP, CO EX, livro 13, p. 101.

42 O livro não evidencia se o autor da proposta foi o padre Antônio de Castro e Silva ou o major João Facundo de Castro e Menezes. Fortaleza, 11 de dezembro de 1829. ATAS do Conselho Geral da Província do Ceará: 1829-1835. Fortaleza: INESP, 1997, p. 159.

43 PROPOSTA do Conselho Geral da Província do Ceará de 25 de janeiro de 1830. ATAS do Conselho Geral da Província do Ceará: 1829-1835. Fortaleza: INESP, 1997, p. 164.

44 ARQUIVO PÚBLICO DO ESTADO DO CEARÁ. Portaria de nomeação de João da Cunha Pereira como diretor dos índios de Messejana. Fortaleza, 19 de fevereiro de 1830, GC, livro 84, p. 156. ARQUIVO NACIONAL, 8J, p. 135.

45 ARQUIVO PÚBLICO DO ESTADO DO CEARÁ. Da câmara de Messejana ao vice-presidente do Ceará. Messejana, 15 de agosto de 1830, CM, MS, pacotilha 1829-1832.

46 Lei n 188 de 22 de dezembro de 1839. In: OLIVEIRA, Almir Leal de. BARBOSA, Ivone Cordeiro (Org.). Leis provinciais: estado e cidadania (1835-1861). Compilação das leis provinciais do Ceará - compreendendo os anos de 1835 e 1861 pelo Dr. Liberato Barroso. Ed. Fac-similada. Fortaleza: INESP, 2009 [1862], tomo I, p. 266. 
João Paulo Peixoto Costa é Professor do Instituto Federal do Piauí, campus de Uruçuí, e do Mestrado Profissional em Ensino de História - PROFHISTÓRIA - da Universidade Estadual do Piauí em Parnaíba. Doutor em História Social pela Universidade Estadual de Campinas, mestre em História do Brasil pela Universidade Federal do Piauí e graduado em História pela Universidade Federal do Ceará. É vice-coordenador do GT "Os índios na História" da Anpuh Brasil e coordena do GT "Os índios na História" da Anpuh Piauí. Compõe a coordenação do Projeto VIP - Vilas Indígenas Pombalinas e atua como pesquisador colaborador do Projeto PARIC/"Respostas Indígenas à Pandemia de Covid-19: Arranjos Sociais e Saúde Global". Participa da organização do canal no YouTube do GT nacional "Os índios na História" da Anpuh Brasil e é membro da Sociedade de Estudos do Brasil Oitocentista (SEBO) da Universidade Federal do Ceará. Pesquisa os índios na história do Ceará entre a crise do Antigo Regime e a formação do Estado nacional brasileiro, com ênfase em políticas indígenas e indigenistas. Atualmente se concentra nos vereadores e juízes indígenas que atuavam nas câmaras municipais de vilas de índios no Ceará entre as décadas de 1750 e 1820. 